\title{
The effects of post-exercise whey vs. casein protein ingestion on muscular strength, muscular endurance, and body composition in older women (50-70 years of age)
}

\author{
Stacie L Urbina*, Andrew White, Josh Shaw, Colin Wilborn, Brian Brabham \\ From International Society of Sports Nutrition: 8th Annual ISSN Conference and Expo \\ Las Vegas, NV, USA. 24-25 June 2011
}

\section{Background}

As humans age, there is a measurable loss of muscle mass that occurs. Termed sarcopenia, this condition not only results in a loss of muscle mass, but also results in a loss of muscular strength and endurance (Bales, 2002). Research has shown that resistance training decreases this loss of muscle mass and muscular strength (Doherty, 2003). However, in older populations, little evidence exists in regards to the addition of whey or casein protein and the effects of each when combined with resistance training. Therefore, the purpose of this study was to examine the effects of whey versus casein protein supplementationcombined with resistance training on muscular strength, muscular endurance and body composition in older females.

\section{Methods}

Nineteen non-resistance trained females $(57.42 \pm 5.32$ yrs, $163.53 \pm 6.42 \mathrm{~cm}, 56.6 \pm 9.47 \mathrm{~kg}$ ) were matched according to bodyweight and total weight lifted and then randomized in a double blind manner to receive either whey $(\mathrm{n}=10)$ or casein protein $(\mathrm{n}=9)$. Participants ingested either casein protein $(24 \mathrm{~g} / \mathrm{d})$ or whey protein $(24 \mathrm{~g} / \mathrm{d}) 30$ minutes to 1 hour post-exercisewhile participating in a high intensity resistance training program ( 3 sets $\mathrm{x} 10$ repetitions at $75 \%$ of $1 \mathrm{RM}$ ), 3 days per week for 8 weeks. Ingestion occurred on non-training days at approximately the same time of day. Testing sessions were completed prior to, 4 weeks and 8 weeks post resistance training and supplementation. Each testing session included body composition measurement as determined by Dual Energy X-Ray Absorptiometry (DEXA), muscle strength measurement as determined by 1 repetition maximum (RM) on leg press and chest press as well a muscular endurance measurement as determined by a repetition to failure test at $75 \%$ of 1 repetition maximum on both the leg press and chest press. Data were analyzed using repeated measures ANOVA.

\section{Results}

A significant time effect was observed for 1RM chest press ( 0 weeks: $40.66 \mathrm{~kg} \pm 6.72 \mathrm{~kg}$ vs. 8 weeks: $55.07 \mathrm{~kg}$ $\pm 10.29 \mathrm{~kg}, \mathrm{p}<0.05)$, leg press (0 weeks: $156.73 \mathrm{~kg} \pm$ $32.69 \mathrm{~kg}$ vs. 8 weeks: $233.13 \mathrm{~kg} \pm 42.5 \mathrm{~kg}, \mathrm{p}<0.05)$, leg press repetition to failure ( 0 weeks: 21.79 vs. 8 weeks: $13.68, \mathrm{p}=0.014$, fat mass ( 0 weeks: $28.19 \mathrm{~kg} \pm 7.05 \mathrm{~kg}$ vs. 8 weeks: $27.39 \mathrm{~kg} \pm 7.09 \mathrm{~kg}, \mathrm{p}=0.015)$, fat free mass $(0$ weeks: $40.22 \mathrm{~kg} \pm 4.35 \mathrm{~kg}$ vs. 8 weeks: $41.69 \mathrm{~kg} \pm 4.62$ $\mathrm{kg}, \mathrm{p}<0.05)$ and percent body fat (0 weeks: $40.93 \%$ $\pm 5.96 \%$ vs. 8 weeks: $39.47 \% \pm 5.88 \%)$. However, no significant group or group by time interactionswere observed.

\section{Conclusion}

When combined with 8-weeks of high intensity resistance training,there is no significant difference in whey versus casein ingestion in regards to their ability to enhance body composition, muscular strength, or muscular endurance in older females. 
doi:10.1186/1550-2783-8-S1-P27

Cite this article as: Urbina et al:: The effects of post-exercise whey vs. casein protein ingestion on muscular strength, muscular endurance, and body composition in older women (50-70 years of age). Journal of the International Society of Sports Nutrition 2011 8(Suppl 1):P27.

Submit your next manuscript to BioMed Central and take full advantage of:

- Convenient online submission

- Thorough peer review

- No space constraints or color figure charges

- Immediate publication on acceptance

- Inclusion in PubMed, CAS, Scopus and Google Scholar

- Research which is freely available for redistribution

Submit your manuscript at www.biomedcentral.com/submit 